\title{
Türkiye ve Avrupa Birliği’nde Ekonomik Büyüme ile Enerji Tüketimi Arasındaki ilişki: Toda-Yamamoto Nedensellik Testi
}

\author{
Füsun YENILMEZ, Mehmet Samet ERDEM*
}

Türkiye ve Avrupa Birliği'nde Ekonomik Büyüme ile Enerji Tüketimi Arasındaki İlişki: Toda-Yamamoto Nedensellik Testi

\section{Özet}

Avrupa Birliği (AB) enerji politikalarına, birliğin temelini oluşturan 1951 tarihli Paris antlaşmasıyla birlikte başlamış, süreç içerisinde de amaç ve ilkelerinde büyük sapmalar göstermemiştir. Günümüzde ise $A B^{\prime}$ nin nükleer enerjiden yenilenebilir enerjiye doğru geçiş yapan politikaları benimsediği görülmektedir. Türkiye ise hızla artan nüfus, yükselen elektrik ihtiyacı, sürekli büyümenin elektrik tüketimini arttırması, enerjideki yüksek dışa bağımlıık, yenilenebilir enerji kaynaklarının artan enerji ihtiyacını karşılamaması gibi nedenlerle nükleer enerjiye geçiş yapan politikaları benimsediği görülmektedir. Enerji türü tercihlerinde görülen bu ayrım, ekonomik büyüme hedefleriyle büyük ölçüde ilişkilidir. Bu çerçevede çalışmada, "Türkiye ve $A B^{\prime}$ de tüketilen enerji türlerinin ekonomik büyüme üzerindeki etkisi nedir?” sorusunun cevabı Toda-Yamamoto nedensellik testi yardımıyla aranmıştır. Çalışmanın sonucunda Türkiye için doğalgaz tüketiminden ekonomik büyümeye doğru, $A B$ için ise petrol tüketiminden ekonomik büyümeye doğru tek yönlü nedensellik ilişkisinin varlığına ulaşımıştır.

Anahtar Kelimeler: Avrupa Birliği, Türkiye, Enerji Tüketimi, Ekonomik Büyüme, Toda-Yamamoto Nedensellik Testi
The Relationship Between Economic Growth and Energy Consumption in Turkey and The European Union: Toda-Yamamoto Causality Test

\section{Abstract}

The European Union (EU) has begun its energy policies with the 1951 Paris treaty, which is the basis of the Union, and has not shown great deviations in its objectives and principles in the process. Nowadays, it is seen that the EU adopts the transition policies from nuclear power to renewable energy. Turkey seems to adopt policies making the transition to nuclear energy because of a rapidly growing population, rising electricity demand, rising electricity consumption by continuous growth, high external dependence on energy and the inability of renewable energy sources to meet the growing energy needs. This distinction, seen in energy type preference, is largely related to economic growth targets. In this context, the answer to the question of "What is the impact of the consumed energy types on the economic growth both in Turkey and EU? has been searched by Toda-Yamamoto causality test. The results indicate that there is a uni-directional causality running from natural gas consumption to economic growth for Turkey and from oil consumption to economic growth for the EU.

Key Words: European Union, Turkey, Energy Consumption, Economic Growth, Toda-Yamamoto Causality Test

\section{Giriş}

Enerji sektörü, ekonomik büyüme üzerindeki etkisi ve diğer sektörlerle olan yapısal bağllığı nedeniyle oldukça önemli bir yere sahiptir. Ekonomik büyümenin enerji ihtiyacını arttırması ve

* Füsun YENILMEZ, Doç.Dr., Eskişehir Osmangazi Üniversitesi,iktisat Bölümü, yenilmez@ogu.edu.tr , ORCID ID orcid.org / 0000-0001-7619-8621; Mehmet Samet ERDEM, Öğr.Gör.Dr., Sinop Üniversitesi Rektörlüğü, mehmetsameterdem@hotmail.com , ORCID ID orcid.org / 0000-0001-7344-2166 
ekonomik büyümenin sağlanabilmesi için enerjiye duyulan ihtiyaç, ekonomik büyüme ve enerji arasında iki yönlü bir tamamlayıcılık ilişkisi olduğunu göstermektedir. Bir ülkede ekonomik büyümenin sağlanabilmesi için gerekli temel girdilerden birisinin enerji olması ekonomik büyüme artarken enerji talebinde de artış meydana getirir. Ayrıca enerji üretiminin artırılabilmesi içinde ekonomik gelişmenin sağlanması gerekir (Uzunöz ve Akçay, 2012, s.2).

Türkiye, sürdürülebilir kalkınma anlayışını hemen hemen her alanda öncelikli hedef olarak benimsemiş ve Altıncı Beş Yıllık Kalkınma Planı ile "sürekli bir ekonomik kalkınmaya imkân verecek şekilde doğal kaynakların yönetimini sağlamak" olarak başladığı hedefini daha sonraki yıllarda enerji ile de ilişkilendirmiştir (ABYKP, 1989, s.312). Onuncu Beş Yıllık Kalkınma Planıyla beraber enerji politikalarının amaç ve hedefleri "Enerjinin nihai tüketiciye sürekli, kaliteli, güvenli, asgari maliyetlerle arzını ve enerji temininde kaynak çeşitlendirmesini esas alarak; yerli ve yenilenebilir enerji kaynaklarını mümkün olan en üst düzeyde değerlendiren, nükleer teknolojiyi elektrik üretiminde kullanmayı öngören, ekonominin enerji yoğunluğunu azaltmayı destekleyen, israfı ve enerjinin çevresel etkilerini asgariye indiren, ülkenin uluslararası enerji ticaretinde stratejik konumunu güçlendiren rekabetçi bir enerji sistemine ulaşılması" olarak belirlenmiştir (OBYKP, 2013, s. 103104).

Avrupa Birliği (AB)'nin bu konudaki temel öncelik alanları ise "rekabet edebilirlik", "iklim değişikliği" ve "temiz ve verimli" enerji olarak belirlenmiştir. AB enerji ithalat kalemlerini azaltarak buradan elde ettiği tasarrufları sürdürülebilir ekonomik büyüme ve yeni istihdam olanaklarının oluşturulmasında kullanmaktadır (Akbaş ve Apar, 2010, s. 5).

Çevrenin korunması ve enerji çeşitliliği gibi konularda gelişmiş ve gelişmekte olan ülkelerin hedefleri birbirinden farklılık göstermektedir. Gelişmiş ve gelişmekte olan ülkelerin politik önceliklerinde görülen bu fark, birçok soruna da farklı pencerelerden bakmalarına neden olmaktadır. Günümüzde bütün ülkeleri ilgilendiren ve etkilerini sıklıkla gördüğümüz küresel ısınma, bu açıdan ülkelerden bağımsız olarak ele alınıp uluslararası işbirliği ile çözüm yollarının aranması gereken evrensel bir sorundur. Buna rağmen gelişmiş ülkelerin verimli ve daha az hava kirliliğini hedefleyen enerji politikaları, gelişmekte olan ülkelerin ekonomik büyüme hedefiyle çizdikleri politikalarla adeta çelişmektedir (Stigson, 1999, s. 428).

Gelişmiş ve gelişmekte olan ülkelerin çevre ve enerji konularına ilişkin hedeflerinde görülen farklılığı, ekonomik büyüme hedeflerinin enerji politikalarıyla olan ilişkisinde de gözlemlemek mümkündür. Banks ve Massy (2012), çalışmalarında gelişmiş dünyanın nükleer santral kullanımından gittikçe uzaklaşırken, pek çok gelişmekte olan ülkenin artan elektrik talebini karşılamak, ithal enerjiye olan bağımlıı̆ı azaltmak, karbondioksit emisyonlarını azaltırken ekonomik büyümeyi teşvik etmek gibi zorluklar nedeniyle nükleer enerjiyi ekonomik kalkınma ve enerji güvenliği stratejilerinin önemli bir parçası olarak gördüğünü ifade etmişlerdir.

$A B$ içerisinde, nükleer enerji üretimi açısından 2016 yılı itibariyle en fazla üretimi toplam üretim içerisindeki \%48 oranla Fransa gerçekleştirmektedir. Fransa'nın ardından Almanya toplam 
üretim içerisindeki \%10 oranla ikinci, Birleşik Kralıı \% 8.5 ile üçüncü ve İsveç \% 7.5 ile dördüncü sıradadır (NES, 2018).

Fransa, elektrik enerjisi üretiminin \%75'ini nükleer enerjiden elde ederken, 2025 yılı hedeflerinde nükleer enerjinin payının \%50'ye düşürüleceğini belirtmiştir. Almanya 2011 yılında meydana gelen Fukushima nükleer felaketinden sonra 17 reaktörünü kapatmış ve 2022 yılının sonuna kadar bütün reaktörlerini kapatacağını belirtmiştir. Birleşik Krallık kullanımda olan 15 reaktörün yaklaşık yarısının 2025 yııına kadar kapatılacağını, İsveç'te benzer biçimde 2015 yılında aldığı kararla 2020 yılına kadar 4 reaktörünü kapatacağını açıklamıştır (WNA, 2018).

Türkiye, 1970 yılından itibaren nükleer enerjiye geçme planlarına Mersin Akkuyu ve Sinop bölgelerine yapacağı iki nükleer santralle ulaşmayı hedeflerken, nükleer enerjiyi ekonomik büyümenin anahtarı olarak görmektedir (WNA, 2018). Bu tablo, AB'nin enerji üretiminin nükleer enerjiden farklılaşan enerji türlerine geçtiğini, Türkiye'nin ise ekonomik büyüme hedeflerinde nükleer enerjinin önemli bir rolü olduğunu göstermektedir.

Ülkelerin nükleer santralleri tercih etmesinin hava kirliliği ve sera gazı emisyonlarını azaltması, elektrik arzıyla bağlantılı olarak maliyet ve belirsizliği en aza indirmesi ve enerji ithalatına bağımlıı̆̆ azaltması gibi avantajları bulunmaktadır. Bu nedenle dünya genelinde ekonomik büyümeyi arttırmak için her zaman büyük bir enerjiye ihtiyaç duyulduğu göz önüne alındığında nükleer enerji gibi kaynakların, operasyonel güvenlik ve radyoaktif atıkların elden çıkarılması gibi riskleri de hesaplayarak, temel enerji kaynağı olarak ele alınması gerekmektedir (Naser, 2015, s: 171).

Ekonomik büyümenin enerji tüketimi ile olan ilişkisi literatürde farklı ülkeler için farklı modeller, zaman periyodları ve değişkenlerle birçok defa incelenmesine rağmen nedenselliğin yönüne ilişkin kanıtlar tartışma konusu olmaya devam etmiştir. Ekonomik büyüme ve enerji tüketimi arasında nedensellik ilişkisi çerçevesinde yapılan ampirik çalışmalar; enerji tüketimindeki bir artışın ekonomik büyüme üzerinde tek yönlü olarak artışa neden olduğu Büyüme Hipotezi, ekonomik büyümedeki artışın enerji tüketimi üzerinde tek yönlü olarak artışa neden olduğu Tasarruf Hipotezi, enerji tüketimi ile ekonomik büyüme arasında bir nedensellik ilişkisinin olmadığı Nötr Hipotezi, enerji tüketimi ve ekonomik büyüme arasında çift yönlü bir nedensellik ilişkisinin olduğu Geri Besleme Hipotezi olarak adlandırılan dört hipotez çerçevesinde sınanmıştır (Souhila ve Kourbali, 2012, ss:2038-239).

Bu çalışmada “Türkiye ve $A B$ 'de tüketilen enerji türlerinin ekonomik büyüme üzerindeki etkisi nedir?" sorusunun cevabı aranarak elde edilecek sonuçlarla Türkiye ile AB'nin karşılaştırılması planlanmaktadır. $A B$ ve Türkiye için ekonomik büyüme ve enerji tüketimi arasındaki ilişki 19862016 yılları arasındaki ekonomik büyüme, petrol, doğalgaz ve kömür tüketimi verileri kullanılarak Toda-Yamamoto nedensellik testi yardımıyla analiz edilecektir. Bu çerçevede enerjinin toplam tüketimi yerine enerji türlerini analize dahil ederek ampirik literatüre katkı sağlamak amaçlanmıştır. 


\section{AB'de Enerji Kullanımı}

$A B^{\prime}$ nin enerji politikası, birliğin temelini oluşturan 1951 yılındaki Paris Antlaşmasıyla kurulan Avrupa Kömür ve Çelik Topluluğu (AKÇT) ile birlikte başlayarak nükleer gücün geliştirilmesine ilişkin işbirliklerini arttırmak amacıyla 1957 yılında kurulan Avrupa Atom Enerjisi Topluluğu (AETT) ile devam etmiştir. Aynı yıl kurulan Avrupa Ekonomik Topluluğu (AET) petrol, doğalgaz ve elektriğe ilişkin sorumlulukları üstlenmiş, 1960'ı yıllarda fark edilen enerji alanındaki eksiklikler ortak bir enerji politikası kurulması amacıyla direktifler ve protokoller yardımıyla giderilmeye çalışımıştır (Yorkan, 2009, ss:25-26).

$A B$ enerji politikası, zaman içerisinde birtakım küçük değişikliklere uğramış olsa bile politikanın amaç, ilke ve ana çizgisinde önemli sapmalar göstermemiş fakat ortak bir politika niteliği de kazanamamıştır. Talep yapısının rasyonelleştirilmesi, arzın geliştirilmesi, enerji ortak pazarının oluşturulması ve teknoloji geliştirmeyi kapsayan politikanın ilkeleri; enerji tüketiminde verimliliğin artmaSI, enerji arz güvenliğinin sağlanması, ürün standartları, fiyatlandırma, vergilendirme vb. birçok alandaki farklııkların giderilmesi ve etkin teknolojilerin geliştirilmesine bağlıdır. Verimliliğin artması enerji konusunda tasarrufu ve çeşitlendirmeyi zorunlu kılarken, teknolojik gelişme birlik için bir başka önemli unsur olan çevre sorunlarının asgariye indirilmesi açısından oldukça önemlidir (Kesbiç ve Şimşek, 2001, ss:11-14).

Gururaja (2003), sosyo-ekonomik hedeflere ulaşmak için sürdürülebilir kalkınma ve enerji ilişkisinin oldukça önemli olduğunu ancak fosil yakıtların atmosferde yarattığı kirlilik ve küresel ısınmanın da göz ardı edilemeyeceğini ifade etmektedir. Bu çerçevede ortaya çıkan tezatlığı dengeleyecek unsur yine ülkelerin belirlediği politikalar ve enerji tercihleridir.

$A B$ bu konudaki hedefini yayınladığı $A B 2020$ stratejisinde, sera gazı salınımının 1990 yılına göre \%20 mümkünse \%30 oranında azaltılması, yenilenebilir enerjide tüketimin payının \%20'ye yükseltilmesi ve \%20 oranında enerji verimliliğinin sağlanması olarak belirlemiştir (IKV, 2014, s. 11). "20-20-20 Hedefleri" olarak da ifade edilen bu hedefler, Türkiye açısından da AB'ye aday ülke konumunda olduğu düşünüldüğünde ulaşılması gereken hedefler konumundadır. 
Şekil 1. AB -28'de Türlere Göre Toplam Enerji Tüketimi (Toplam Tüketim İ̧indeki Yüzde Payı)

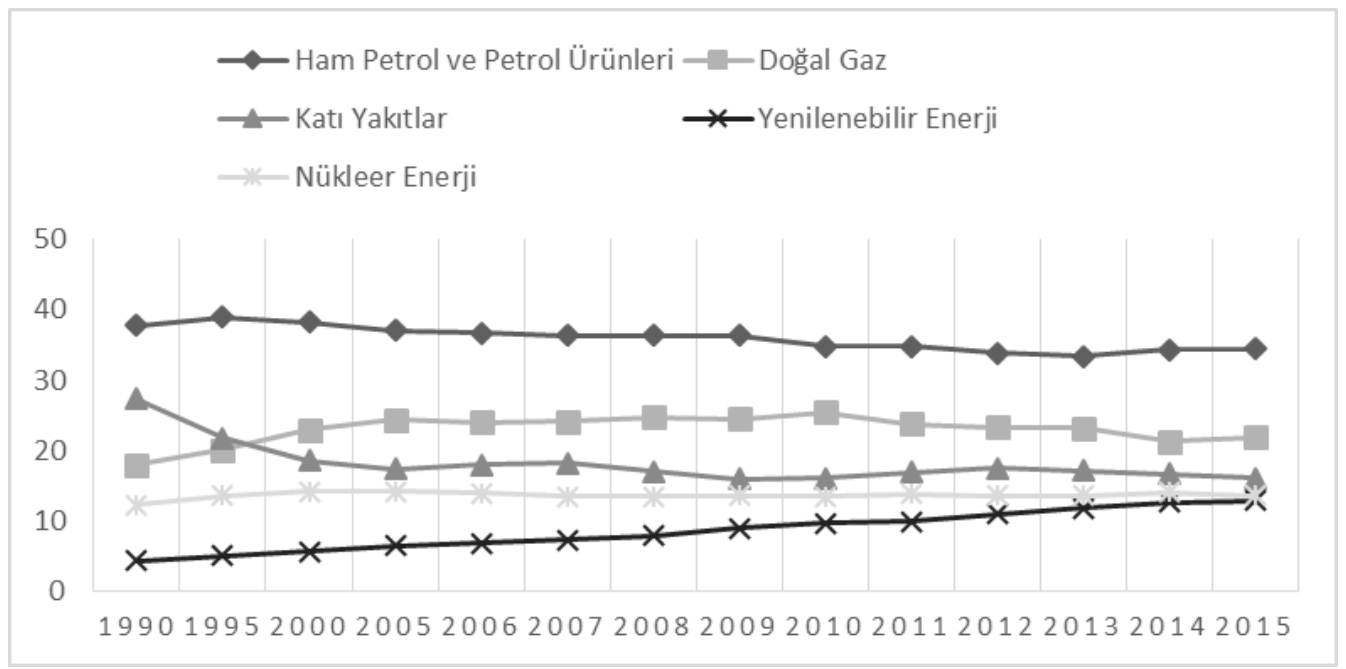

Kaynak: EUROSTAT verileriyle derlenmiş̧tir.

Şekil 1, AB'nin 1990-2015 yılları arasındaki türlere göre toplam enerji tüketimini göstermektedir. $A B^{\prime}$ nin 26 ylllık süreçte ham petrol ve petrol ürünleri ve katı yakıt gibi sera gazı salınımının en büyük nedenleri olarak sayabileceğimiz enerji kaynak kullanımını gittikçe azalttı̆̆ı, bunun yanı sıra yenilenebilir enerji kaynaklarını ve doğal gaz kullanımını artırdığı görülmektedir. Nükleer enerji tüketimi ise hemen hemen aynı seyirde ilerlemiştir.

\section{Şekil 2. AB-28'de Sera Gazı Emisyonu ( $\mathrm{CO}_{2}$ Eş Değeri)}

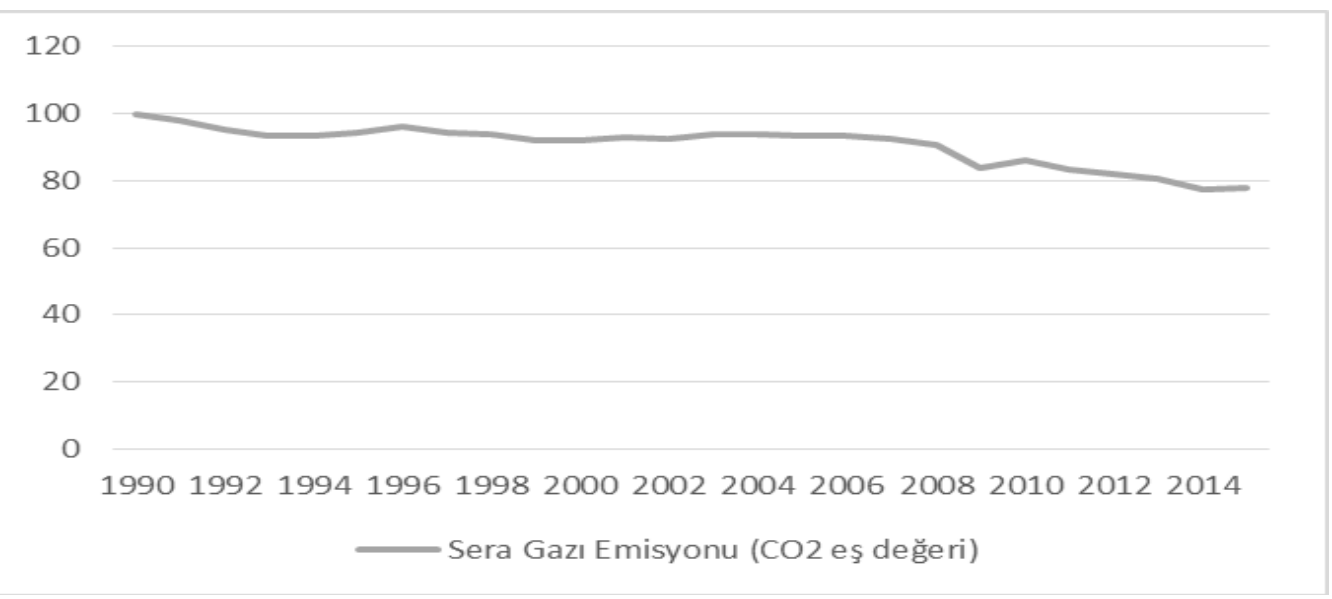

Kaynak: EUROSTAT verileriyle derlenmiştir. 
Şekil 2, AB'nin sera gazı emisyonunun 25 yıllık seyrini göstermektedir. AB 2020 stratejisinde belirtildiği gibi, 1990 yılını baz alarak bakıldığında, 2011 yılında sera gazı emisyonu yaklaşık \%18, 2012 yılında ise yaklaşık \%21 oranında azalmıştır (EU, 2018). AB'nin 2020 yılına kadar sera gazı emisyonlarının 1990 yılına göre \%20 azaltma hedefine şimdiden ulaştığı görülürken, yakaladığı trend açısından, sera gazı emisyonlarını \%30 azaltılması hedefine de ulaşabileceği öngörülmektedir.

Sera gazı emisyonunda elde edilen bu başarı, petrol ve katı yakıt kullanımındaki azalışların yanında yine hedef olarak belirlenen yenilenebilir enerji kaynaklarının artmasıyla da ilişkilidir. Yenilenebilir enerji kaynaklarının \%20'ye çıkarılması için atılan adımlar her ne kadar olumlu olsa da 2016 yılı itibariyle bu oran \%16.8 olarak açıklanmıştır (EEA Report, 2017: 64). 2020 hedefine doğru ilerleyen $A B^{\prime}$ nin yenilenebilir enerji kaynaklarını \%20'ye çıkarma hedefine ulaşıp ulaşamayacağı tartışılırken 2017 sonlarında yayınlanan raporla 2030 yılına kadar enerjinin \%27'sinin yenilebilir kaynaklardan elde etme hedefi \%35'e çıkarılmıştır (EU, 2017).

\section{Türkiye'de Enerji Kullanımı}

Daha önce de ifade edildiği gibi, gelişmiş dünyanın nükleer santralden uzaklaşan politikalarına karşılık gelişmekte olan bir ülke olarak Türkiye'nin büyüme ve enerji ilişkisine bakış açısı $A B^{\prime}$ den ayrışan bir yapı sergilemektedir. $A B$ enerji tercihinde nükleer enerjiden yenilebilir enerjiye doğru geçiş yapan politikaları benimserken, Türkiye hızla artan nüfus, yükselen elektrik ihtiyacı, sürekli büyümenin elektrik tüketimini arttırması, enerjideki yüksek dışa bağımlılık, yenilenebilir enerji kaynaklarının artan enerji ihtiyacını karşılamaması gibi nedenlerle (ETKB, 2018) önceliğini enerjiyi kaliteli, ucuz, sürekli, verimli ve dışa bağımlıı̆̆ı en alt düzeye indirerek temin edebilmek için nükleer enerjiye geçiş politikalarını benimsemektedir (ETKB, 2016, ss: 5-22). 
Şekil 3. Enerji Türlerine Göre Türkiye'nin Dışa Bağımlılığı (\%)

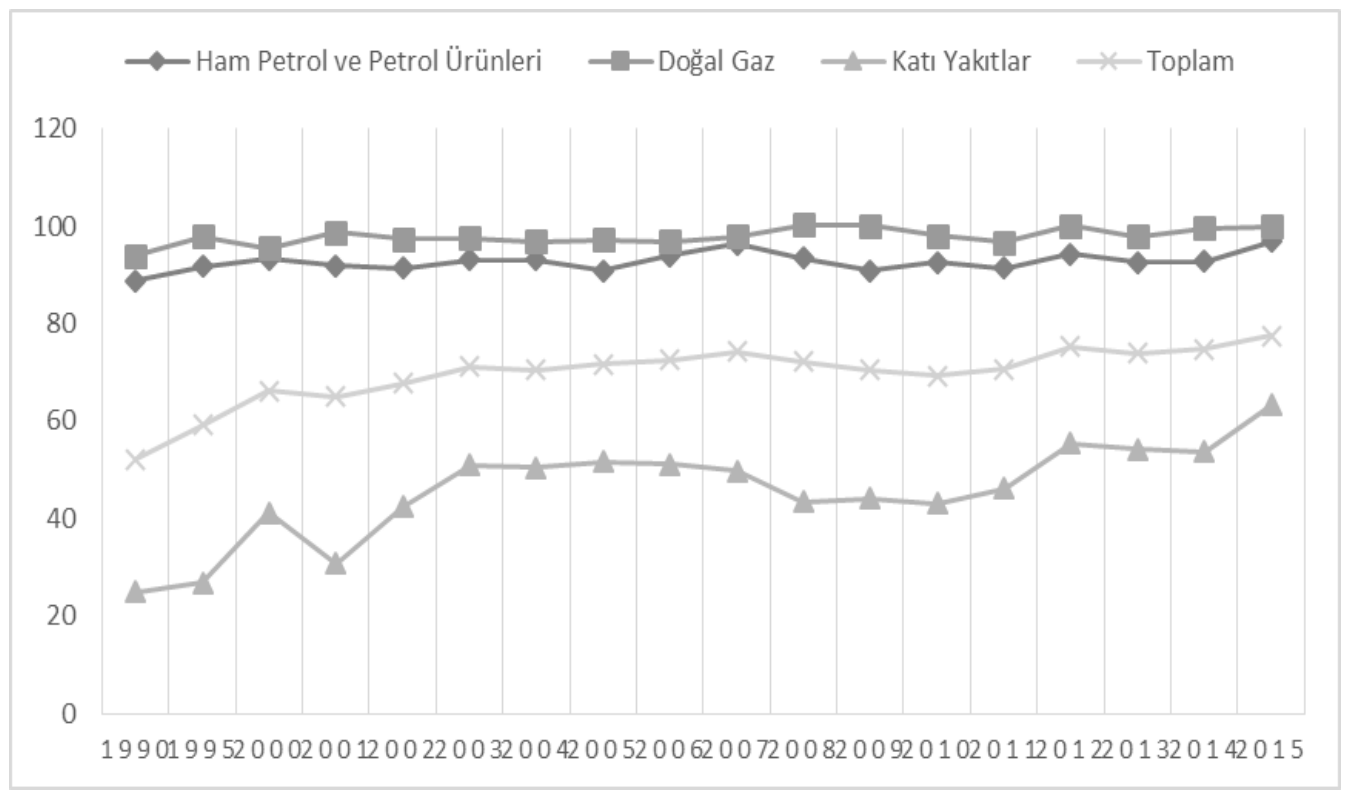

Kaynak: EUROSTAT verileriyle derlenmiş̧tir.

Türkiye'nin enerjide olan dışa bağımlıı̆ı̆ nükleer enerji tercihi ile azalacak olmasa da bağımlıı̆ı çeşitlendirmek için bir araç niteliğindedir. Şekil 3'de Türkiye'nin enerji türlerine göre dışa bağımlılı̆ı görülmektedir. Birincil enerji kaynakları içerisinde 2015 ylına göre katı yakıtlara olan bağımlılı̆ı yaklaşık \%54, ham petrol ve doğal gaza \%90, toplamda $\% 77,5$ oranında dışa bağımlı olması, Türkiye'nin enerjide çok büyük oranda dışa bağlı olduğunun göstergesi niteliğindedir (EUROSTAT). 
Şekil 4. Türkiye’de Türlere Göre Toplam Enerji Tüketimi (\% toplam tüketim içinde)

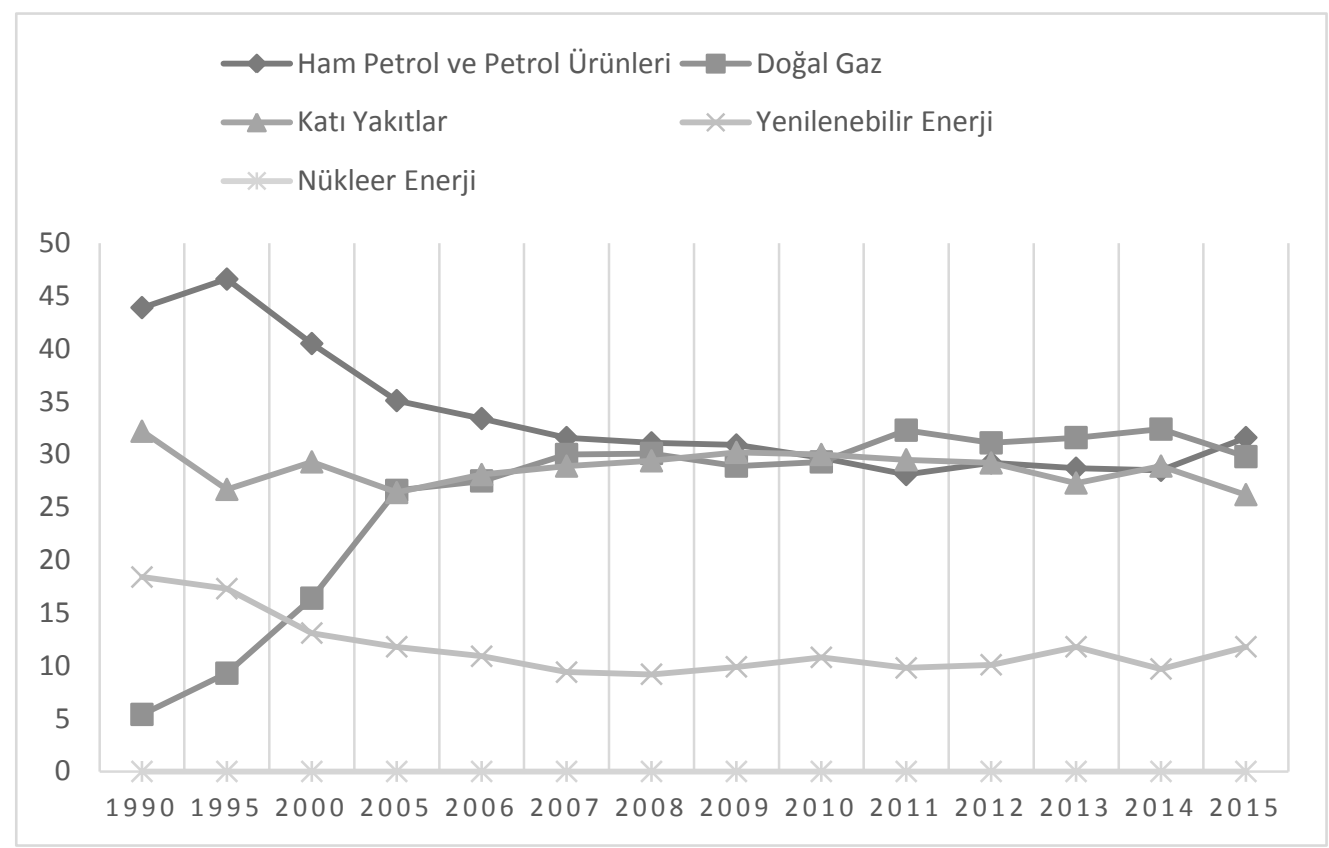

Kaynak: EUROSTAT verileriyle derlenmiştir.

Şekil 4, Türkiye'deki türlere göre toplam enerji tüketimini göstermektedir. Zaman içerisinde ham petrol ve petrol ürünleri tüketiminde büyük ölçüde azalış görülürken, doğal gaz tüketiminde ise büyük ölçüde artış görülmektedir. Katı yakıt tüketimine bakıldığında tüketimin toplam enerji tüketimi içerisindeki payı 2015 yılı itibariyle 1995 yılı seviyelerinde olduğu görülürken, yenilenebilir enerjinin toplam enerji tüketimi içerisindeki oranı 1990'lı yılların altında yer alarak 2015 yılı itibariyle 2005 yılı seviyesinde olduğu görülmektedir.

Gültekin ve Örgün (1993), doğal gazın yanması sonucunda atmosfere kükürt gaz salınımları olmadığı için havayı kirletecek etki yaratmadığı, özellikle petrol kullanımına göre daha çevreci oluğunu ifade etmişlerdir.

EPA (2015), ise doğal gazın ana bileşeni olan metan gazında yanmanın tamamen oluşmadığı, taşınma ve sızıntı gibi durumlarda sera gazı salınımına neden olduğunu fakat enerji santrallerinde kullanımı sonucunda petrol ve kömüre göre daha az oranda karbondioksit ve nitrojen oksit açığa çıkardığını belirtmiştir. Çevresel açıdan Türkiye'nin ham petrol ve petrol ürünlerinin ve katı yakıtların kullanımında görülen azalışın yanında doğal gaz kullanımının artması olumlu bir gelişme olarak görülmektedir. 
Şekil 5, Türkiye için sera gazı emisyonunun yıllar içerisindeki değişimini göstermektedir. Bu bağlamda Türkiye'nin sera gazı salınım değerleri yıllar itibariyle sürekli artan bir trend göstermektedir. Kömür ve petrol ürünleri gibi yüksek oranda sera gazı salınımına neden olan enerji türlerinin daha az kullanılmasına rağmen böyle bir trend içinde olmasının nedeninin tüketimde meydana gelen yüksek orandaki artış olduğu düşünülmektedir.

\section{Şekil 5. Türkiye için Sera Gazı Emisyonu ( $\mathrm{CO}_{2}$ Eş Değeri)}

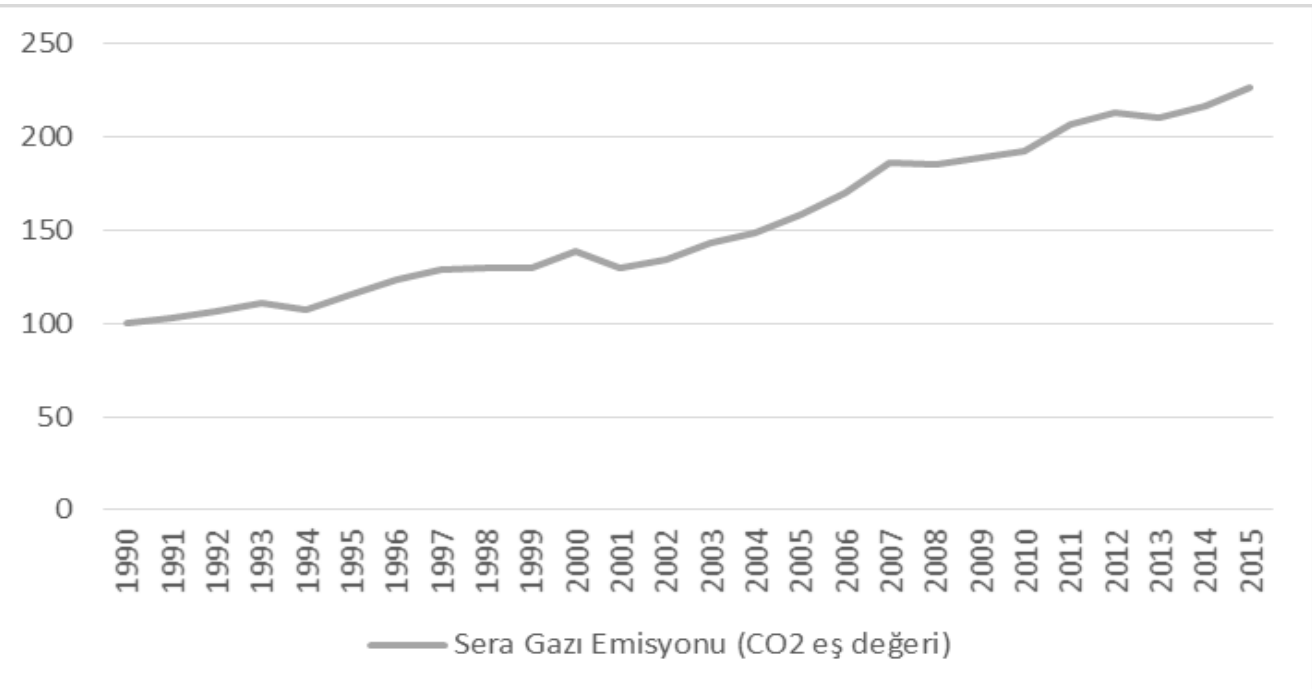

Kaynak: EUROSTAT verileriyle derlenmiştir.

Sera gazı emisyonunda görülen bu artış, AB'nin belirlediği 2020 yılına kadar 1990 yılına kıyasla \%20 oranında sera gazı emisyonunun azaltılması hedefleri içerisinde çok uzak bir yerde konumlanmaktadır. Tüketimin sera gazı emisyonunda yaratmış olduğu bu etki yenilenebilir ve nükleer enerji gibi alternatif enerji kaynaklarının kullanımıyla çözülebilecek olsa da kısa vadede çözülebilecek bir sorun olmadığı açıktır. Türkiye'nin 2015 yılı itibariyle \%11,8 olan enerji tüketimindeki yenilenebilir enerjinin oranı 2013 yılı için AB'nin yenilenebilir enerjinin kullanım yüzdesiyle eşit bir değere sahiptir (EUROSTAT). Bu durum kuşkusuz tam üyelik yolunda önemli görünse de çerçevenin tümüne yetmemektedir.

\section{Literatür}

Enerji tüketimine ilişkin yapılan çalışmaların çoğu ekonomik büyüme ile olan ilişkisi bakımından incelenmiştir. Çalışmalarda elde edilen sonuçların kullanılan yöntemin biçimine, ülkelere ve ele alınan döneme göre farklılık gösterdiği görülmektedir.

Alanda yapılan ilk çalışmalardan birisi Rasche ve Tatom (1977) tarafından, enerjiyi üretim fonksiyonuna dâhil ederek ekonomik büyüme ve elektrik tüketimini ilişkilendirerek yapılmıştır. Bu 
çalışmayı takiben, Kraft ve Kraft (1978) brüt enerji tüketimi ve ekonomik büyüme arasındaki ilişkiyi nedensellikle açıklayan çalışmayı ortaya koyarak ekonomik büyümeden enerji tüketimine doğru tek yönlü nedensellik ilişkisi olduğu sonucuna ulaşmışlardır. Kraft ve Kraft (1978)'ın bu çalışması, Akarca ve Long (1980) tarafından dışsal etkiler nedeniyle analizi etkileyecek bazı dönemlere ait verilerin analize dâhil edilmesi yönünden eleştirilmiş ve dışsal etkilerden arındııımış yeni veri setiyle yaptıkları analizde değişkenler arasında nedenselliğin bulunmadığını belirtmişlerdir.

Alanda yer alan diğer bir grup çalışmada ise GSMH ile Enerji Tüketimi arasındaki ilişki incelenmiştir. Bunlardan birisi Yu ve Hwang (1984) tarafından yapılan çalışmadır. Yu ve Hwang, 1947-1979 dönemini kapsayan çalışmalarında Granger nedensellik analizini kullanarak ABD için GSMH ile enerji tüketimi arasında nedensellik ilişkisinin olmadığını ifade etmişlerdir.

Stern (1993), ABD için 1947-1990 yılları arasındaki emek ve sermayenin yer aldığı üretim fonksiyonuna enerjiyi dâhil ederek GSYH ile toplam enerji tüketimi arasında herhangi bir nedensellik ilişkisine rastlamamıştır.

Altınay ve Karagöl (2005), Türkiye için 1950-2000 dönemini kapsayan çalışmalarında reel GSYH ve toplam elektrik tüketimi arasındaki nedensellik ilişkisini incelemiş, elektrik tüketiminden reel GSYH'ye doğru tek yönlü nedensellik ilişkisi tespit etmişlerdir.

Karanfil (2008) , Türkiye özelinde yaptığı çalışmasında 1970- 2005 yılları arasındaki reel GSYH ile enerji tüketimi arasındaki ilişkiyi inceleyerek değişkenler arasında herhangi bir ilişkiye rastlamamıştır.

Ouedraogo (2013), 1980-2008 dönemini kapsayan 15 Afrika ülkesini içeren Batı Afrika Eyaletleri (ECOWAS) için yaptığı çalışmasında VECM ve Granger nedensellik analizi kullanarak kısa dönemde GSYH'den enerji tüketimine, uzun dönemde ise enerji tüketiminden GSYH'ya doğru tek yönlü nedensellik ilişkisi olduğu sonucuna ulaşmıştır.

Saad ve Taleb (2018)çalışmasında konuya yeni bir bakış açısı getirmiş ve ekonomik büyüme ile yenilenebilir enerji arasındaki ilişkiyi analiz etmiştir. Bu çalışmada Saad ve Taleb, 1990-2014 yıllarını kapsayan 12 Avrupa Birliği ülkesi için panel VECM, ECM ve Granger nedensellik analizi kullanarak yaptıkları çalışmalarında uzun dönem için ekonomik büyüme ve yenilenebilir enerji arasında çift yönlü, kısa dönem için ekonomik büyümeden yenilenebilir enerjiye doğru tek yönlü nedensellik ilişkisi olduğunu tespit etmişlerdir.

Tablo 1'de, enerji tüketimi ve ekonomik büyüme arasındaki ilişkinin farklı yöntemlerle test edildiği çalışmalar yer almaktadır. 
Tablo 1. Enerji Tüketimi Ve Ekonomik Büyüme İlişkisine Ait Çalışmaların Literatür Özeti

\begin{tabular}{|c|c|c|c|c|}
\hline $\begin{array}{l}\text { Çalışma- } \\
\text { nın Yılı }\end{array}$ & Yazar(lar) & $\begin{array}{l}\text { Verilerin Yılı ve } \\
\text { Kapsamı }\end{array}$ & Yöntem & Sonuç \\
\hline 2005 & $\begin{array}{l}\text { Altınay ve } \\
\text { Karagöl }\end{array}$ & 1950-2000, Türkiye & $\begin{array}{l}\text { Dolado-Lütkepohl VAR, } \\
\text { Granger Nedensellik Testi }\end{array}$ & $\mathrm{ET} \rightarrow \mathrm{EB}$ \\
\hline 2006 & $\begin{array}{l}\text { Şengül ve } \\
\text { Tuncer }\end{array}$ & 1960- 2000, Türkiye & $\begin{array}{l}\text { Toda - Yamamoto Arttırılmış } \\
\text { VAR, }\end{array}$ & $\mathrm{ET} \rightarrow \mathrm{EB}$ \\
\hline 2007 & $\begin{array}{l}\text { Jobert ve } \\
\text { Karanfil }\end{array}$ & 1960-2003, Türkiye & $\begin{array}{l}\text { Johansen Eşbütünleşme } \\
\text { Testi ve Granger Nedensellik } \\
\text { Analizi }\end{array}$ & EB - ET \\
\hline 2008 & Kar ve Kınık & 1975-2005, Türkiye & $\begin{array}{l}\text { Johansen Eşbütünleşme } \\
\text { Testi ve VECM }\end{array}$ & $\mathrm{ET} \rightarrow \mathrm{EB}$ \\
\hline 2009 & $\begin{array}{l}\text { Mucuk ve } \\
\text { Uysal }\end{array}$ & 1960-2006, Türkiye & $\begin{array}{l}\text { Johansen Eşbütünleşme } \\
\text { Testi ve Granger Nedensellik } \\
\text { Analizi }\end{array}$ & $\mathrm{ET} \rightarrow \mathrm{EB}$ \\
\hline 2009 & $\begin{array}{l}\text { Soytaş ve } \\
\text { Sarı }\end{array}$ & 1960-2000, Türkiye & $\begin{array}{l}\text { VAR ve Granger Nedensellik } \\
\text { Analizi }\end{array}$ & EB - ET \\
\hline 2010 & Sharma & $\begin{array}{l}\text { 1986-2005, } 66 \text { ülke } \\
\text { ve Avrupa }\end{array}$ & Panel Veri Analizi & $\mathrm{ET} \rightarrow \mathrm{EB}$ \\
\hline 2010 & $\begin{array}{l}\text { Noor ve } \\
\text { Siddiqi }\end{array}$ & $1971-2006$ & $\begin{array}{l}\text { Panel Veri Analizi, } \\
\text { ECM ve FMOLS }\end{array}$ & $\mathrm{EB} \rightarrow \mathrm{ET}$ \\
\hline 2010 & Pao ve Tsai & $\begin{array}{l}\text { 1971-2005, BRIC } \\
\text { ülkeleri }\end{array}$ & $\begin{array}{l}\text { Johansen Fisher Panel } \\
\text { Eşbütünleşme Testi, ECM ve } \\
\text { VECM Granger Nedensellik } \\
\text { Analizi }\end{array}$ & $\mathrm{EB} \leftrightarrow \mathrm{ET}$ \\
\hline 2011 & Hossain & $\begin{array}{l}\text { 1971-2007, } 9 \text { Yeni } \\
\text { Sanayileşen Ülke }\end{array}$ & $\begin{array}{l}\text { Johansen Fisher Panel } \\
\text { Eşbütünleşme Testi, ECM ve } \\
\text { Granger Nedensellik Analizi }\end{array}$ & EB - ET \\
\hline 2012 & $\begin{array}{l}\text { Korkmaz ve } \\
\text { Develi }\end{array}$ & 1960-2009, Türkiye & $\begin{array}{l}\text { Johansen Eşbütünleşme } \\
\text { Testi ve Granger Nedensellik } \\
\text { Analizi }\end{array}$ & $\mathrm{EB} \leftrightarrow \mathrm{ET}$ \\
\hline 2012 & $\begin{array}{l}\text { Pirlogea ve } \\
\text { Cicea }\end{array}$ & $\begin{array}{l}\text { 1990-2010, İspanya, } \\
\text { Romanya ve AB }\end{array}$ & $\begin{array}{l}\text { Hsiao Granger Nedensellik } \\
\text { Testi }\end{array}$ & $\begin{array}{l}\text { AB için : } \\
\text { EB - ET }\end{array}$ \\
\hline 2013 & Uzun vd. & 1980-2010, Türkiye & $\begin{array}{l}\text { VECM, Johansen } \\
\text { Eşbütünleşme Testi ve } \\
\text { Granger Nedensellik Testi }\end{array}$ & $\mathrm{EB} \rightarrow \mathrm{ET}$ \\
\hline 2014 & $\begin{array}{l}\text { Erdoğan ve } \\
\text { Gürbüz }\end{array}$ & 1970-2009, Türkiye & $\begin{array}{l}\text { Gregory-Hansen } \\
\text { Eşbütünleşme Testi ve } \\
\text { Granger Nedensellik Analizi }\end{array}$ & EB - ET \\
\hline
\end{tabular}


Füsun YENILMEZ | Mehmet Samet ERDEM

\begin{tabular}{lllll}
\hline 2014 & Bayar & 1961-2012, Türkiye & $\begin{array}{l}\text { ARDL, ECM, Todo- } \\
\text { Yamamoto Nedensellik Testi } \\
\text { Panel Veri Analizi }\end{array}$ & EB $\leftrightarrow$ ET \\
2014 & $\begin{array}{l}\text { Bölük ve } \\
\text { Mert }\end{array}$ & 1990-2008, AB16 & EB - ET \\
2015 & $\begin{array}{l}\text { Ergün ve } \\
\text { Polat }\end{array}$ & $\begin{array}{l}\text { 1980-2010, OECD } \\
\text { Ülkeleri }\end{array}$ & $\begin{array}{l}\text { Panel Eşbütünleşme Testi, } \\
\text { VECM }\end{array}$ & EB $\leftrightarrow$ ET \\
& $\begin{array}{l}\text { Aydın ve } \\
\text { Bozdağ }\end{array}$ & $\begin{array}{l}\text { 1960-2014, Türkiye } \\
\text { ve AB }\end{array}$ & $\begin{array}{l}\text { Johansen Eşbütünleşme } \\
\text { Testi, ECM ve Granger Ne- } \\
\text { densellik Analizi }\end{array}$ & ET $\rightarrow$ EB \\
\hline
\end{tabular}

Kaynak: Yazarlar tarafından oluşturulmuştur.

Not: EB: Ekonomik Büyüme, ET: Enerji Tüketimi, VECM: Vektör Hata Düzeltme Modeli, ECM: Hata Düzeltme Modeli, VAR: Vektör Otoregresif Model, FMOLS: Tamamen Değiştirilmiş En Küçük Kareler, ARDL: Otoregresif Dağıtılmış Gecikme Modeli, $\leftrightarrow$ çift yönlü nedensellik ilişkisi, $\rightarrow$ : tek yönlü nedensellik ilişkisi, - : nedensellik ilişkisinin olmadığı durumu ifade etmektedir.

\section{Metodoloji}

Granger nedensellik testi bir çok akademik disiplinin ampirik çalışmalarında oldukça yaygın olarak kullanılmaktadır. Rastsal bir $X$ değişkeninin geçmişi, diğer bir rastsal $Y$ değişkeninin geleceğine ilişkin daha iyi bir tahmin imkanı sağlıyorsa, $X$ değişkeni $Y$ değişkeninin Granger nedenidir biçiminde tanımlanmaktadır (Atukeren, 2011, ss:137-138). Aralarında bir ilişki olup olmadığı sorgulanan değişkenler arasındaki ilişkinin varlığını ortaya koymak ve ilişkinin varlığı durumunda da söz konusu ilişkinin yönünü belirlemek amacıyla aşağıda yer alan eşitlikle test edilir (Uzunöz ve Akçay, $2012, \mathrm{~s}: 8)$.

$$
\begin{gathered}
Y_{t}=\sum_{i=1}^{m} \lambda_{i} Y_{t-i}+\sum_{i=1}^{m} \alpha_{i} X_{t-i}+\mu_{1 t} \\
X_{t}=\sum_{i=1}^{m} \sigma_{i} X_{t-i}+\sum_{i=1}^{m} \theta_{i} Y_{t-i}+\mu_{2 t}
\end{gathered}
$$

Eşitlikte yer alan $\lambda_{i}, \alpha_{i}, \sigma_{i}, \theta_{i}$ gecikme katsayılarını, $\mu_{1 t}$ ve $\mu_{2 t}$ korelasyonsuz beyaz süreçleri ve $m$ bütün değişkenler için ortak gecikme derecesini göstermektedir. Granger (1969)'ın eşitliğine göre $X_{t}^{\prime}$ nin hem kendi geçmiş değerleri hem de $Y_{t}^{\prime}$ nin geçmiş değerleri ile ilişkili olduğu; $Y_{t}^{\prime} n i n$ de aynı biçimde kendi geçmiş değerleri ve $X_{t}$ nin geçmiş değerleriyle ilişkili olduğunu göstermektedir.

Granger nedensellik testi uygulanırken değişkenlerin durağanlık şartı aranmaktadır. Durağan olmayan serilerin farkı alınarak durağanlık şartının sağlanması gerekmektedir. Bunun yanı sıra 
Granger nedensellik testi gecikme sayısına oldukça duyarlıdır. Gecikme sayısına olan duyarlılığı sebebiyle de uygun gecikme sayısının belirlenmesi doğru sonuca ulaşılması açısından önemlidir.

Granger nedensellik testinin Granger (1988) tarafından geliştirilmesiyle durağan olmayan seriler arasındaki nedensellik ilişkisinin analizi de mümkün olmaktadır. Durağan olmayan serilerin analizi için serilerin aynı dereceden bütünleşik olması ve seriler arasında eşbütünleşme ilişkisinin olması gerekmektedir. Bunun yanı sıra, Toda-Yamamoyo (1995) tarafından geliştirilen yöntemle serilerin aynı dereceden bütünleşik olma şartı aranmazken aynı zamanda bu seriler arasında eşbütünleşme ilişkisinin varlığına da ihtiyaç duyulmamaktadır (Çalışkan, Karabacak ve Meçik, 2017, s.50).

Toda-Yamamoto testi VAR modeline dayanmaktadır. VAR modelinin optimal gecikme uzunluğu $(k)$ ve serilerin en büyük durağanlık derecesi $\left(d_{\max }\right)$ belirlendikten sonra $\left(k+_{d \max }\right)$ boyutunda VAR modeli tahmin edilir ve model aşağıdaki gibi tanımlanır.

$$
\begin{aligned}
& Y_{t}=\varpi+\sum_{i=1}^{k} \alpha_{1 i} X_{t-i}+\sum_{i=1}^{k} \beta_{1 i} Y_{t-i}+\sum_{j=m+1}^{d \max } \delta_{1 i} X_{t-i}+\sum_{j=m+1}^{d \max } \theta_{1 i} Y_{t-i}+\varepsilon_{1 t} \\
& X_{t}=\partial+\sum_{i=1}^{k} \alpha_{2 i} X_{t-i}+\sum_{i=1}^{k} \beta_{2 i} Y_{t-i}+\sum_{j=m+1}^{d \max } \delta_{2 i} X_{t-i}+\sum_{j=m+1}^{d \max } \theta_{2 i} Y_{t-i}+\varepsilon_{2 t}
\end{aligned}
$$

Eşitlikte yer alan $k$ uygun gecikme uzunluğunu, $d_{\max }$ bütünleşme derecelerinin en büyüğünü göstermektedir. Hata terimleri olan $\varepsilon_{1 t}$ ve $\varepsilon_{2 t}$ sifır ortalama ve sabit kovaryans matrisine sahip olduğu varsayılır. Değişkenler arasındaki nedenselliğin varlığı $H_{0}: \alpha_{1 i}=0$ ve $H_{0}: \alpha_{2 i}=0$ hipotezleri vasıtasıyla düzeltilmiş WALD test istatistiği kullanarak sınanır ve hesaplanan test istatistiği tablo değerinden büyük olması durumunda hipotezler reddedilir (Gazel, 2017: ss:291-292).

Toda-Yamamoto testi uygulanmadan önce herhangi bir ön test yapma koşulu bulunmamaktadır fakat maksimum bütünleşme derecesinin elde edilebilmesi için analiz öncesinde birim kök testleri uygulanmalıdır. Testin ikinci aşaması uygun gecikme sayısının belirlenmesinden oluşmaktadır. Ancak bilgi kriterlerinin önerdiği uygun gecikme sayıları genellikle VAR modelinin istikrar koşulunu sağlaması, değişen varyansın ve otokorelasyonun giderilmesi için yeterli değildir. Bunun için bilgi kriterleri ve tanılayıcı testler yardımıyla uygun gecikme sayısı belirlenmelidir. Son olarak TodaYamamoto testinin uygulanabilmesi için serilerin maksimum bütünleşme derecesi $\left(d_{\max }\right)$, modelin optimal gecikme sayısını (k) geçmemelidir (Çalışkan, Karabacak ve Meçik, 2017, ss.50-52).

\section{Yöntem ve Veriler}

Çalışmada AB ve Türkiye'ye için 1986-2016 yılları arasındaki ekonomik büyüme, petrol, doğalgaz ve kömür değişkenleri kullanılmıştır. Bu bağlamda enerji türleri bakımından petrol tüketiminin milyon ton cinsinden değeri, doğalgaz tüketiminin milyon ton petrol cinsinden değeri ve kömür 
tüketiminin milyon ton petrol cinsinden değeri, ekonomik büyüme göstergesi olarak da yıllık bazda büyüme oranı seçilmiştir. AB'ye ilişkin veriler, söz konusu yıllar için birliğin toplamı biçiminde analize dâhil edilmiştir.

Analiz içerisinde petrol tüketimi değişkeni “PT”, kömür tüketimi değişkeni "KT", doğalgaz tüketimi değişkeni “DT" ve ekonomik büyüme değişkeni “EB” olarak gösterilmiştir. Ekonomik büyümeye ait veriler Dünya Bankası (World Development Indicators) veri tabanından, enerji tüketimine ait veriler ise British Petroleum (BP Statistical Review of World Energy June 2017) veri tabanından derlenmiştir.

Analizde öncelikle değişkenlerin birim kök testleri yapılmış ardından, değişkenler arasındaki olası bir yüksek çoklu bağlantı sorunu olup olmadığını görmek için korelasyon matrisine bakılmıştır. Toda-Yamamoto nedensellik testinin ilk aşaması olarak yapılan birim kök testi sonucuna göre maksimum bütünleşme derecesi belirlenmiş, ikinci aşamada VAR modeli için optimal gecikme sayısı bilgi kriterleri ve tanımlayıcı testler yardımıyla belirlenerek değişkenler arasındaki nedensellik ilişkisi analiz edilmiştir.

\section{Ampirik Test ve Bulgular}

Analize dâhil edilen değişkenlerin öncelikle düzey değerlerinde durağan olup olmadıklarına, düzey değerde durağan olmayan seriler görülürse birinci farkları alınarak durağanlık koşulunu sağlayıp sağlamadığına bakılmıştır. Tablo 2 ve Tablo 3 , sırasıyla $A B$ ve Türkiye için, analizde kullanılacak olan değişkenlerin Augmented Dickey-Fuller(ADF) birim kök testi sonuçlarını göstermektedir.

Tablo 2. Augmented Dickey-Fuller(ADF) Birim Kök Testi Sonuçları (AB)

\begin{tabular}{lll}
\hline \hline Değişkenler & Düzey Değerleri & Birinci Fark Değerleri \\
\hline EB & $-3.711080^{* * *}$ & - \\
PT & -2.393752 & $-3.192796^{* *}$ \\
KT & -1.422037 & $-3.816721^{* * *}$ \\
DT & -1.769839 & $-5.849282^{* * *}$ \\
\hline
\end{tabular}

$* * * \% 1, * * \% 5$ anlamlılığı göstermektedir. 
Tablo 3. Augmented Dickey-Fuller(ADF) Birim Kök Testi Sonuçları (Türkiye)

\begin{tabular}{lll}
\hline \hline Değişkenler & Düzey Değerleri & Birinci Fark Değerleri \\
\hline EB & $-5.729833^{* * *}$ & - \\
PT & -0.408951 & $-2.691498^{*}$ \\
KT & 0.499460 & $-7.658900^{* * *}$ \\
DT & 0.049980 & $-3.911216^{* * *}$ \\
\hline
\end{tabular}

***\%1, *\%10 anlamlılığı göstermektedir.

Tablo 2 ve Tablo 3'de görüldüğü Türkiye'nin ve AB'nin ekonomik büyüme değişkeni (EB) düzeyde durağanken petrol tüketimi (PT), kömür tüketimi (KT) ve doğal gaz tüketimine (DT) ait veriler düzeyde durağan olma koşulunu sağlayamadıkları için birinci farkları alındığında durağan oldukları görülmektedir.

Tablo 4 ve Tablo 5 , $A B$ ve Türkiye için kullanılacak bağımlı ve bağımsız değişkenlere ait korelasyon matrisini göstermektedir. Tabloya göre $A B$ için doğal gaz tüketimi ile kömür tüketimi arasında, Türkiye için doğal gaz tüketimi ile petrol ve kömür tüketimi arasında yüksek düzeyde çoklu doğrusal bağlantı görülmektedir. Bu durumda değişkenlerin aynı anda analize dâhil edilmesinin güvenilir sonuçlar vermeyebileceği düşüncesiyle bağımsız değişkenler olan petrol tüketimi, doğal gaz tüketimi ve kömür tüketimi, bağımlı değisken olan ekonomik büyüme ile ayrı ayrı analiz edilecektir.

Tablo 4. AB'ye İlişkin Verilerin Korelasyon Matrisi

\begin{tabular}{llllc}
\hline \hline & $E B$ & $P T$ & $K T$ & $D T$ \\
\hline EB & 1 & 0.204 & 0.405 & -0.248 \\
PT & 0.204 & 1 & 0.04 & 0.42 \\
KT & 0.405 & 0.04 & 1 & -0.783 \\
DT & -0.2482 & 0.425 & -0.783 & 1 \\
\hline
\end{tabular}


Füsun YENILMEZ | Mehmet Samet ERDEM

Tablo 5.Türkiye'ye İlişkin Verilerin Korelasyon Matrisi

\begin{tabular}{lllll}
\hline \hline & $E B$ & $P T$ & $K T$ & $D T$ \\
\hline EB & 1 & 0.04 & 0.07 & 0.09 \\
PT & 0.04 & 1 & 0.84 & 0.83 \\
KT & 0.07 & 0.84 & 1 & 0.96 \\
DT & 0.09 & 0.83 & 0.96 & 1 \\
\hline
\end{tabular}

Verilere ait bilgiler çerçevesinde analizde, aşağıda yer alan modeller kullanılacaktır.

$$
\begin{gathered}
E B_{i t}=\beta_{0}+\beta_{1} P T_{i t}+e_{i t} \\
E B_{i t}=\beta_{0}+\beta_{1} D T_{i t}+e_{i t} \\
E B_{i t}=\beta_{0}+\beta_{1} K T_{i t}+e_{i t}
\end{gathered}
$$

Modeller içerisinde bağımlı değişken olarak yer alan EB ekonomik büyümeyi, bağımlı değişkenlerden (5) numaralı denklemde yer alan PT petrol tüketimini, (6) numaralı denklemde yer alan DT doğalgaz tüketimini, (7) numaralı denklemde yer alan KT kömür tüketimini, $\beta_{0}$ sabit terimi ve $e_{i t}$ hata terimini göstermektedir. Kurulan bu modeller $A B$ ve Türkiye için ayrı ayrı analiz edilerek sonuçları karşılaştıılacaktır.

Tablo 2 ve Tablo 3'de görüldüğü gibi bağımlı değişken olan EB düzeyde durağan haldeyken, bağımsız değişkenleri oluşturan petrol, doğalgaz ve kömür tüketimi bileşenleri birinci farkları alındığında durağan hale gelmektedir.

Toda-Yamamoto testinin ilk aşaması maksimum bütünleşme derecesinin belirlenmesinden oluşmaktadır. Tablo 2 ve Tablo 3'de yer alan ADF Birim Kök Testine göre durağan olmayan bütün seriler birinci farklarında durağanlaşmaktadır. Bu sonuca göre, hem $A B$ hem de Türkiye için maksimum bütünleşme derecesi $\left(d_{\max }\right) 1$ olarak görülmektedir.

Ikinci aşamada VAR modeli için optimal gecikme sayısı belirlenmelidir. Şekil 6 ve Şekil 7, sırasıyla $A B$ ve Türkiye için uygun gecikme uzunluklarına göre oluşturulmuş $A R$ Karakteristik Polinomunun Ters Köklerinin grafiklerini, Tablo 6 ve Tablo 7 Otokolerasyon LM Testi sonuçlarını, Tablo 8 ve Tablo 9 White Değişen Varyans testinin sonuçlarını göstermektedir. 
Şekil 6. AB için AR Karakteristik Polinomunun Ters Kökleri

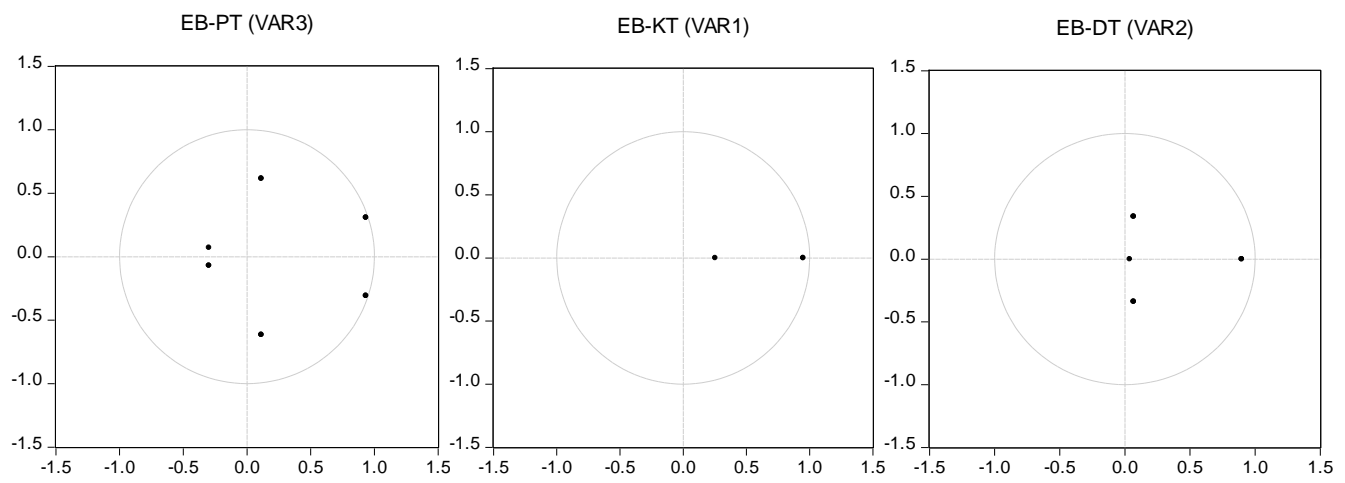

Şekil 7. Türkiye için AR Karakteristik Polinomunun Ters Kökleri
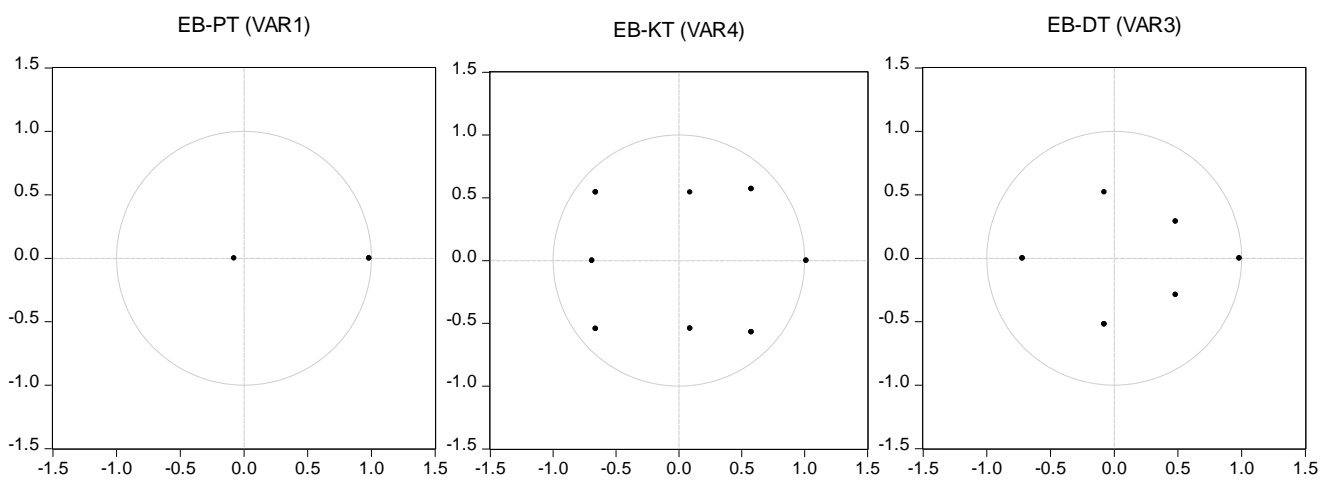

Tablo 6. Otokolerasyon LM Testi Sonuçları (AB)

\begin{tabular}{cccc}
\hline \hline Model & Gecikme & LM istatistiği & Olasılık \\
\hline \multirow{2}{*}{ EB-PT (VAR3) } & 1 & 2.998577 & 0.5581 \\
& 2 & 2.187903 & 0.7012 \\
EB-KT (VAR1) & 3 & 1.912151 & 0.7519 \\
& 1 & 3.614611 & 0.4607 \\
EB-DT(VAR2) & 2 & 2.733569 & 0.6034 \\
& 3 & 3.923085 & 0.4165 \\
& 1 & 2.998577 & 0.5581 \\
& 2 & 2.187903 & 0.7012 \\
\end{tabular}


Füsun YENILMEZ | Mehmet Samet ERDEM

Tablo 7. Otokolerasyon LM Testi Sonuçları (Türkiye)

\begin{tabular}{cccc}
\hline \hline Model & Gecikme & LM istatistiği & Olasılık \\
\hline \multirow{2}{*}{ EB-PT (VAR1) } & 1 & 5.176354 & 0.2697 \\
& 2 & 2.756067 & 0.5994 \\
EB-KT (VAR4) & 3 & 2.503905 & 0.6439 \\
& 1 & 3.018496 & 0.5547 \\
EB-DT(VAR3) & 2 & 3.105559 & 0.5403 \\
& 3 & 1.507728 & 0.8253 \\
& 1 & 4.945516 & 0.2929 \\
& 2 & 0.913227 & 0.9227 \\
\end{tabular}

Tablo 8. White Değişen Varyans Testinin Sonuçları (AB)

\begin{tabular}{cccc}
\hline \hline Model & Ki-Kare & Serbestlik Derecesi & Olasılık \\
\hline EB-PT (VAR3) & 46.37028 & 36 & 0.1154 \\
EB-KT (VAR1) & 16.13153 & 12 & 0.1853 \\
EB-DT(VAR2) & 35.19122 & 24 & 0.0656 \\
\hline
\end{tabular}

Tablo 9. White Değişen Varyans Testinin Sonuçları (Türkiye)

\begin{tabular}{cccc}
\hline \hline Model & Ki-Kare & Serbestlik Derecesi & Olasıllk \\
\hline EB-PT (VAR1) & 13.62512 & 12 & 0.3253 \\
EB-KT (VAR4) & 49.48866 & 48 & 0.4136 \\
EB-DT(VAR3) & 45.57591 & 36 & 0.1316 \\
\hline
\end{tabular}

Bilgi kriterleri ve tanılayıcı testlerin yardımıyla, $A B$ özelinde ekonomik büyüme-petrol tüketimi için 3, ekonomik büyüme-kömür tüketimi için 1, ekonomik büyüme-doğalgaz tüketimi için 2 gecikme uzunluğu belirlenirken; Türkiye için ekonomik büyüme-petrol tüketimi için 1, ekonomik büyüme-kömür tüketimi için 4, ekonomik büyüme-doğalgaz tüketimi için 3 gecikme uzunluğu 
belirlenmiştir. Belirlenen gecikme uzunlukları çerçevesinde hem $A B$ hem de Türkiye için bütün değişkenlerin AR polinomunun ters kökleri birim çember içindedir ve otokolerasyon ya da değişen varyans problemi taşımamaktadır.

Tablo 10 ve Tablo 11, yukarıda belirlenen gecikme uzunluklarına değişkenlerin maksimum bütünleşme derecesi $\left(d_{\max }=1\right)$ eklenerek analiz edilmiş Toda-Yamamoto nedensellik testi sonuçlarını göstermektedir.

Tablo 10. Toda-Yamamoto Nedensellik Testi Sonucu (AB)

\begin{tabular}{llll}
\hline \hline Model & $k+d_{\max }$ & $\begin{array}{l}\text { Olasılık Değeri ve } \\
\text { işareti }\end{array}$ & Nedenselliğin Yönü \\
\hline EB-PT & $3+1=4$ & 0.7571 & PT $\rightarrow$ EB \\
PT-EB & & 0.0235 & \\
EB-KT & $1+1=2$ & 0.6387 & EB-KT \\
KT-EB & & 0.5314 & \\
EB-DT & $2+1=3$ & 0.3746 & EB-DT \\
DT-EB & & 0.8074 & \\
\hline
\end{tabular}

Tablo 10'a göre $A B$ için petrol tüketiminden ekonomik büyümeye doğru tek yönlü nedensellik ilişkisine rastlanırken, ekonomik büyümenin doğalgaz ve kömür tüketimi ile aralarında herhangi bir nedenselliğe rastlanamamıştır.

Tablo 11.Toda-Yamamoto Nedensellik Testi Sonucu (Türkiye)

\begin{tabular}{llll}
\hline \hline Model & $k+d_{\max }$ & $\begin{array}{l}\text { Olasılık Değeri ve } \\
\text { işareti }\end{array}$ & $\begin{array}{l}\text { Nedenselliğin } \\
\text { Yönü }\end{array}$ \\
\hline EB-PT & $1+1=2$ & 0.2539 & EB-PT \\
PT-EB & & 0.1315 & \\
EB-KT & $4+1=5$ & 0.5315 & EB-KT \\
KT-EB & & 0.8661 & \\
EB-DT & $3+1=4$ & 0.8589 & DT $\rightarrow$ EB \\
DT-EB & & 0.0552 & \\
\hline
\end{tabular}

Tablo 11'e göre Türkiye için doğalgaz tüketiminden ekonomik büyümeye doğru tek yönlü nedensellik ilişkisine rastlanırken, ekonomik büyümenin petrol ve kömür tüketimi ile aralarında herhangi bir nedenselliğe rastlanamamıştır.

\section{Sonuç}

$A B$, enerji politikalarıyla belirlediği hedeflerine somut adımlarla devam etmektedir. Bu adımlar içerisinde sera gazı emisyonuna ilişkin elde ettiği başarıı sonuçlar en öne çıkanı olurken, yenilenebi- 
Füsun YENILMEZ | Mehmet Samet ERDEM

lir enerji açısından daha yavaş bir ivmeyle hareket etse de uzun vadede koyduğu hedeflerin mevcut hedeflerin de ötesinde bir başarıya işaret ettiği görülmektedir.

Gelişmiş dünyanın nükleer santral kullanımından gittikçe uzaklaşmasına ilişkin düşünce çerçevesinde, $A B^{\prime}$ nin yenilenebilir enerji kullanımının özellikle nükleer enerji kullanımının yerine geçmesi yönünde yaptığı çalışmaların temelinde bünyesinde barındırdığı ülkelerin sanayisindeki gelişmişliklerinin sağladığı ekonomik rahatlık olduğu düşünülmektedir.

Türkiye'nin benimsediği politikalar ise büyüme öncelikleri doğrultusunda enerji tercihlerini şekillendirmektedir. Enerjiye büyük oranda dışa bağlı olmasının yanında hızla artan nüfus ve enerji tüketimi, enerji tercihinde de $A B^{\prime}$ den farklılaşmasının nedeni olarak görülmektedir. Bu bağlamda yenilenebilir enerji yatıımları, nükleer enerjiye yapılması planlanan yatıımların gölgesinde kalmaktadır. Yine de yenilenebilir enerjinin mevcut durumu açısından AB'nin geneline bakıldığında çok gerilerde kalmadığı görülmüştür.

Türkiye, aslında bütün ülkelerin farklı zamanlarda yaptığı gibi, enerji tüketimini kömür ve petrolden ayrıştırarak doğal gaza doğru yöneltmiş, fakat bu durum enerjideki dışa bağımlılık konusunda bağımlılı̆ın çeşitlendirilmesi dışında bir kazanım sağlamamıştır. Dahası, doğal gaza geçişle beraber sera gazı emisyonunda olumlu bir gelişme gösterememiş, aksine artan tüketimle birlikte çok ciddi oranlarda artan bir seyir göstermiştir.

Bu görünüm temelinde, “ $A B$ ve Türkiye'de tüketilen enerji türlerinin ekonomik büyüme üzerindeki etkisi nedir?" sorusunun cevabını aradığımı çalışmanın ampirik analizinden elde edilen bulgular, $A B$ için kömür ve doğalgaz tüketimi ile ekonomik büyüme arasında nedensellik ilişkisi olmadığını gösterirken, petrol tüketiminden ekonomik büyümeye doğru tek yönlü bir nedenselliği göstermektedir. Büyüme Hipotezi olarak adlandırılan nedensellik ilişkisinin sonucuna göre petrol özelindeki tasarruf politikalarının ekonomik büyüme üzerinde olumsuz etki yapacağı söylenebilir. Bunun yanı sıra petrol tüketiminde meydana gelen artışların ekonomik büyümeyi de arttırabileceği, ekonomik büyümeyi sağlayacak olan yapının petrole dayandığı biçiminde yorumlanabilir.

Türkiye için yapılan analizin sonuçları doğalgaz tüketiminden ekonomik büyümeye doğru tek yönlü bir nedenselliği gösterirken, petrol ve kömür tüketiminin ekonomik büyüme ile herhangi bir nedensellik ilişkisi olmadığını göstermektedir. Türkiye özelinde yapılan analizin sonucunda görülen nedensellik ilişkisi, AB özelinde varılan sonuç gibi, Büyüme Hipotezi olarak adlandırılmaktadır. Bu bağlamda doğalgaz üzerinde uygulanacak olan tasarruf politikaları ekonomik büyüme üzerinde olumsuz etkilere neden olabilecektir. Yine doğalgaz tüketimindeki artışların ekonomik büyümeyi de arttırabileceği sonucu Türkiye'de ekonomik büyümeyi sağlayıcı yapının doğalgaza dayandığını düşündürmektedir.

Gerek $A B^{\prime}$ nin petrol tüketimine gerekse Türkiye'nin doğalgaz tüketimine dayalı büyüme sonu$\mathrm{cu}$, enerjide bağımlılık sorununu işaret etmektedir. $A B$ ve Türkiye, bu çerçevede görülen enerji bağımlılığı problemini çözebilecek politikalar geliştirmesi gerekmektedir. Bu politikaları geliştirirken 
yenilenebilir enerjiye yatırım yapmak özellikle Türkiye açısından bağımlılık sorununa çözüm oluşturabilecekken, 2011 yılındaki sera gazı emisyonu değeriyle $A B$ içerisindeki en yüksek değere sahip 5. ülke konumundaki olumsuz görünümünü düzeltebilir ve AB'nin "20-20-20 Hedefleri” olarak belirlediği hedefler açısından tam üyelik yolunda önemli adımlar atmasını sağlayabilir.

\section{Kaynaklar}

AB 2020 (2010). Europe 2020: A European strategy for smart, sustainable and inclusive growth. European Commission, Brussels.

ABYKP (1989). Altıncı Beş Yıllık Kalkınma Planı. Kalkınma Bakanlığı.

Akarca, A. T. \& Long, T. V. (1980). On the relationship between energy and GNP: a reexamination. The Journal of Energy and Development, 326-331.

Akbaş, G. ve Apar, A. (2010). Avrupa 2020 Stratejisi: Akıllı, Sürdürülebilir ve Kapsayıcı Büyüme için Avrupa Stratejisi Özet Bilgi Notu. Avrupa Birliği Genel Sekreterliği.

Altinay, G. \& Karagol, E. (2004). Structural break, unit root, and the causality between energy consumption and GDP in Turkey. Energy Economics, 26(6), 985-994.

Altinay, G. \& Karagol, E. (2005). Electricity consumption and economic growth: Evidence from Turkey. Energy Economics, 27(6), 849-856.

Atukeren, E. (2011). Granger-Nedensellik Sınamalarına Yeni Yaklaşımlar. Atatürk Üniversitesi iktisadi ve Idari Bilimler Dergisi, 25, 137-153.

Aydın, B. \& Bozdağ, A. (2018). Elektrik Tüketimi ve Ekonomik Büyüme Arasındaki iliş̧ki: Avrupa Birliği ve Türkiye Örneği, International Journal of Academic Value Studies, Vol: , Issue: pp:7080.

Banks. J.P ve Massy, K. (2012). Nuclear Power in Developing Countries? Let's Talk about It. https://www.brookings.edu/opinions/nuclear-power-in-developing-countries-lets-talk-aboutit/ [Erişim: 23.05.2018].

Bayar, Y. (2014). Türkiye'de Birincil Enerji Kullanımı ve Ekonomik Büyüme. Atatürk Üniversitesi Iktisadi ve Idari Bilimler Dergisi, 28(2).

Bölük, G., \& Mert, M. (2014). Fossil \& renewable energy consumption, GHGs (greenhouse gases) and economic growth: Evidence from a panel of EU (European Union) countries. Energy, 74, 439-446.

BP, Statistical Review of World Energy, June 2017.

https://www.bp.com/content/dam/bp/en/corporate/excel/energy-economics/statisticalreview-2017/bp-statistical-review-of-world-energy-2017-underpinning-data.xlsx

[Erişim: 18.09.2017]. 
Füsun YENILMEZ | Mehmet Samet ERDEM

Çalışkan, Ş., Karabacak, M. \& Meçik, O. (2017). Türkiye Ekonomisinde Eğitim Harcamaları ve Ekonomik Büyüme ilişkisi: Bootstrap Toda-Yamamoto Nedensellik Testi Yaklaşımı. Kocaeli Üniversitesi Sosyal Bilimler Enstitüsü Dergisi, KOSBED 33 (1), 45-56.

EEA Report (2017). Renewable energy in Europe- 2017 Update Recent growth and knock-on effects. European Environment Agency Report No: 23/2017.

EPA (2015). United States Environmental Protection Agency. http://www.epa.gov/cleanenergy/energy-and-you/affect/natural-gas.html [Erişim: 05.05.2015].

Erdoğan, S., \& Gürbüz, S. (2014). Türkiye'de Enerji Tüketimi Ve Ekonomik Büyüme Ilişkisi: Yapısal Kırılmalı Zaman Serisi Analizi. Selçuk Üniversitesi Sosyal Bilimler Enstitüsü Dergisi, (32), 79-87.

Ergün, S., \& Polat, M. A. (2015). OECD Ülkelerinde Co2 Emisyonu, Elektrik Tüketimi Ve Büyüme Ilişkisi. Erciyes Üniversitesi Iktisadi ve Idari Bilimler Fakültesi Dergisi, (45), 115.

ETKB (2006). 2006 Yılı Enerji Ve Tabii Kaynaklar Bakanlığı Faaliyet Raporu. Türkiye Cumhuriyeti Enerji Ve Tabii Kaynaklar Bakanlığı, Ankara.

ETKB (2014). Nükleer Santraller Ve Ülkemizde Kurulacak Nükleer Santrale ilişkin Bilgiler. Türkiye Cumhuriyeti Enerji ve Tabii Kaynaklar Bakanlığı Nükleer Enerji Proje Uygulama Dairesi Başkanlığı. Yayın No:1.

ETKB (2018). Enerji Ve Tabii Kaynaklar Bakanlığı Nükleer Santral Bilgilendirme Kitapçığı. Türkiye Cumhuriyeti Enerji Ve Tabii Kaynaklar Bakanlığı, Ankara

EU (2017). European Parliament Report: On the proposal for a directive of the European Parliament and of the Council on the promotion of the use of energy from renewable sources (recast) (COM(2016)0767 - C8 0500/2016 - 2016/0382(COD)). Committee on Industry, Research and Energy, A8-0392/2017.

EU (2018). 2020 Climate \& Energy Package. https://ec.europa.eu/clima/policies/strategies/2020 en . [Erişim: 23.05.2018].

EUROSTAT. Muhtelif yıllar veri setleri.

NES (2018). Nuclear Energy Statistics. EUROSTAT. http://ec.europa.eu/eurostat/statisticsexplained/index.php?title=Nuclear energy statistics. [Erişim: 23.05.2018].

Gazel, S. (2017). BisT Sınai Endeksi İle Çeşitli Metaller Arasındaki ilişki: Toda-Yamamoto Nedensellik Testi.

Akademik Sosyal Araştırmalar Dergisi, 5(52), 287-299.

Granger, Clive W. J. (1969). Investigating Causal Relation by Econometric and Cross-Sectional Method. Econometrica, 37, 424-438. 
Granger, Clive W. J. (1988). Some Recent Developments in the Concept of Causality. Journal of Econometrics, 39, 199-211.

Gururaja, J. (2003). Energy For Sustainable Development: Review of national and international energy policies. Natural Resources Forum. 27 pp.53-67.

Gültekin, A.H. \& Örgün, Y. (1993). Doğal Gaz ve Çevre, Ekoloji Çevre Dergisi, Sayı: 9, 37 - 41, EkimKasım-Aralık 1993.

Hossain, M. S. (2011). Panel estimation for CO2 emissions, energy consumption, economic growth, trade openness and urbanization of newly industrialized countries. Energy Policy, 39(11), 6991-6999.

IKV (2014). Avrupa 2020 Stratejisi. Iktisadi Kalkınma Vakfı Yayınları Yayın No: 269.

Jobert, T., \& Karanfil, F. (2007). Sectoral energy consumption by source and economic growth in Turkey. Energy Policy, 35(11), 5447-5456.

Kar, M., \& Kınık, E. (2008). Türkiye'de elektrik tüketimi çeşitleri ve ekonomik büyüme arasındaki ilişkinin ekonometrik bir analizi. Afyon Kocatepe Üniversitesi IiBF Dergisi, 10(2), 333-353.

Karanfil, F. (2008). "Energy Consumption and Economic Growth Revisited: Does The Size of Unrecorded Economy Matter?”, Energy Policy, 36 (8), 3029-3035.

Kesbiç, C. Y., \& Şimşek, H. (2011). Avrupa Birliği Ortak Enerji Politikası. Sosyal Ve Beşeri Bilimler Araştırmaları Dergisi, 1(5).

Korkmaz, Ö., \& Develi, A. (2012). Türkiye'de Birincil Enerji Kullanımı, Üretimi Ve Gayri Safi Yurt İçi Hasıla (GSYH) Arasındaki Ilişki. Dokuz Eylül Üniversitesi Iktisadi ve Idari Bilimler Fakültesi Dergisi, 27(2), 1-25.

Kraft, J., \& Kraft, A. (1978). On the relationship between energy and GNP. The Journal of Energy and Development, 401-403.

Mucuk, M., \& Uysal, D. (2009). Türkiye ekonomisinde enerji tüketimi ve ekonomik büyüme. Maliye Dergisi, 157, 105-115.

Naser, H. (2015). Can nuclear energy stimulates economic growth? Evidence from highly industrialised countries. International Journal of Energy Economics and Policy, 5(1), 164.

Noor, S., \& Siddiqi, M. W. (2010). Energy consumption and economic growth in South Asian countries: a co-integrated panel analysis. International Journal of Human and Social Sciences, 5(14), 921-926.

OBYKP (2013). Onuncu Beş Yıllık Kalkınma Planı. Kalkınma Bakanlığı.

Ouedraogo, N. S. (2013). Energy consumption and economic growth: Evidence from the economic community of West African States (ECOWAS). Energy economics, 36, 637-647. 
Pao, H. T., \& Tsai, C. M. (2010). CO2 emissions, energy consumption and economic growth in BRIC countries. Energy policy, 38(12), 7850-7860.

Pirlogea, C., \& Cicea, C. (2012). Econometric perspective of the energy consumption and economic growth relation in European Union. Renewable and Sustainable Energy Reviews, 16(8), 5718-5726.

Rasche, R. H., \& Tatom, J. A. (1977). Energy resources and potential GNP. Federal Reserve Bank of St. Louis Review, (Jun), 10-24.

Saad, W., \& Taleb, A. (2018). The causal relationship between renewable energy consumption and economic growth: Evidence from Europe. Clean Technologies and Environmental Policy, 1-10.

Sharma, S. S. (2010). The relationship between energy and economic growth: Empirical evidence from 66 countries. Applied energy, 87(11), 3565-3574.

Souhila, C., \& Kourbali, B. (2012). Energy consumption and economic growth in Algeria: Cointegration and causality analysis. International Journal of Energy Economics and Policy, 2(4), 238-249.

Soytas, U., \& Sari, R. (2009). Energy consumption, economic growth, and carbon emissions: challenges faced by an EU candidate member. Ecological economics, 68(6), 1667-1675.

Stern, D. I. (1993). Energy and economic growth in the USA: A multivariate approach. Energy economics, 15(2), 137-150

Stigson, B. (1999). Sustainable development for industry and society. Building Research and Information 27(6), pp.424-430.

Şengül, S., \& Tuncer, i. (2006). Türkiye'de enerji tüketimi ve ekonomik büyüme: 1960-2000. İktisat isletme ve Finans, 21(242), 69-80.

Toda, Hiro Y. and Taku Yamamoto (1995). Statistical Inference in Vector Autoregressions with Possibly Integrated Processes. 66, 225-250.

Uzun, A., Emsen, Ö. S., Yalçıkaya, Ö., \& Hüseyni, i̇. (2013). Toplam elektrik üretimi ve ekonomik büyüme ilişkisi: Türkiye örneği (1980-2010). Atatürk Üniversitesi Sosyal Bilimler Enstitüsü Dergisi, 17(3), 327-344.

Uzunöz,M.,Akçay,Y. (2012). Türkiye'de büyüme ve enerji tüketimi arasındaki nedensellik ilişkisi:1970-2000, Çankırı Karatekin Üniversitesi Sosyal Bilimler Enstitüsü Dergisi 3(2):001-016.

World Development Indicators, 2017.

http://databank.worldbank.org/data/reports.aspx?source=world-development-indicators . [Erişim: 18.09.2017]. 
WNA (2018). World Nuclear Association http://www.world-nuclear.org/informationlibrary/country-profiles.aspx. [Erişim: 23.05.2018].

Yorkan, A. (2009). Avrupa Birliği'nin Enerji Politikası ve Türkiye'ye Etkileri. Bilge Strateji, 1(1), 24-39.

Yu, Eden S. H. \& Hwang, B. K. (1984). The relationship between energy and GNP: Further results. Energy Economics, 6(3), 186-190. 